\title{
Expression of genes that regulate Fas signalling and Fas-mediated apoptosis in colon carcinoma cells
}

\author{
David M. Tillman ${ }^{1}$, Franklin G. Harwood ${ }^{1}$, Alice A. Gibson ${ }^{1}$ \\ and Janet A. Houghton ${ }^{1,2}$ \\ 1 Department of Molecular Pharmacology, St. Jude Children's Research \\ Hospital, 332 North Lauderdale, Memphis, Tennessee 38105, USA \\ 2 corresponding author: JA Houghton, Tel: (901) 495-3440; \\ fax: (901) 521-1668
}

Received 2.10.97; revised 18.11.97; accepted 8.1.98 Edited by D. Green

\begin{abstract}
The expression of genes that regulate Fas-induced apoptosis has been examined in 10 human cultured colon carcinoma cell lines with defined and varied sensitivity to the cytolytic antiFas MoAb CH-11. Four lines demonstrated sensitivity to $\mathrm{CH}-11$ $\left(\mathrm{HT29}, \mathrm{GC}_{3} / \mathrm{c} 1, \mathrm{TS}^{-}\right.$, Thy4), and six were resistant to the induction of apoptosis vis Fas. In nine lines expressing Fas, PCR-sequencing indicated that the death domain contained wt sequences. Downstream of Fas, expression of FADD/MORT1 and FLICE, essential components of the DISC, and negative regulators of Fas signalling including sFas, FAP-1 and Bcl-2, showed no correlation between levels of expression and sensitivity to Fas-mediated cytotoxicity. However, levels of the Fas antigen varied by $>1000$-fold, and correlated with $\mathrm{CH}$ 11 sensitivity. Following fourfold elevation in Fas expression in HT29 cells treated with interferon- $\gamma$, a synergistic effect on Fas-mediated apoptosis was obtained when $\mathrm{CH}-11$ and interferon $-\gamma$ were combined.
\end{abstract}

Keywords: Fas signalling; gene expression; apoptosis; colon carcinoma cells

Abbreviations: TS, thymidylate synthase; DISC, death-inducingsignalling-complex; ICE, interleukin-1 $\beta$ converting enzyme; FAP, fas-associated phosphatase; TNF, tumor necrosis factor

\section{Introduction}

Fas, a type I transmembrane protein, comprises a cell surface receptor and is a member of the TNF receptor superfamily. When activated by crosslinking either with the natural ligand FasL (Suda et al, 1993) or with an agonistic Ab (Trauth et al, 1989), apoptosis can be induced. Fas has been considered to be primarily involved in the regulation of apoptosis in cells of the immune system during normal tissue homeostasis (French et al, 1996). However, the Fas antigen is expressed in a wide variety of normal cell and tissue types, including cells of the thymus, lung, spleen, small and large intestines, seminal vesicle, prostate and uterus, which demonstrate high rates of cell turnover and apoptotic cell death (French et al,
1996; Leithauser et al, 1993). The role of Fas in regulating apoptotic responses in cells outside of the immune system remains unknown. However, Fas-dependent apoptosis has been identified in several malignant cell types, including malignant cells of the colon (Houghton et al, 1997a; Rokhlin et al, 1997; Weller et al, 1994).

In the normal colon, Fas is constitutively expressed in every epithelial cell of the crypt and mucosal surface (Moller et al, 1994), suggesting that it may be involved in the regulation of normal cell turnover. We (Houghton et al, 1997a) and others (Meterissian and Kontogiannea, 1996; Moller et al, 1994) have shown Fas to be expressed in cultured colon carcinoma cell lines, as well as in colon carcinomas (Moller et al, 1994). Previously we have shown that the cytolytic anti-Fas MoAb $\mathrm{CH}-11$ can induce apoptosis in colon carcinoma cells of the $\mathrm{GC}_{3} / \mathrm{c} 1$ lineage, although Fas-mediated apoptosis does not occur in all malignant cells of this histiotype (Houghton et al, 1997b). In addition, $\mathrm{TS}^{-}$cells that were selected from wt $\mathrm{GC}_{3} / \mathrm{c} 1$ cells for thymidylate synthase (TS)-deficiency undergo apoptosis via thymineless death when dThd is withdrawn from the medium, an event which is mediated via autocrine signalling through Fas/FasL interactions following the induction of DNA damage (Houghton et al, 1997a).

For Fas-dependent apoptosis to occur in colon carcinomas, all components of the Fas signalling pathway must be present. Following trimerization of the receptor after stimulation, several proteins (CAP1-4) have been identified that bind to the intracellular death domain of Fas to form the death-inducing-signalling-complex (DISC). CAP1 and CAP2 comprise the death domain signalling molecule FADD/MORT1 (Boldin et al, 1995; Chinnaiyan et al, 1995), which recruit FLICE (CAP4), a FADD/MORT1homologous ICE/CED-3-like protease to the DISC (Boldin et al, 1996; Medema et al, 1997; Muzio et al, 1996). Following release of active FLICE from the DISC, a cascade of ICE-like proteases is activated. However, modification of any one of the components of the Fas signalling pathway either by mutation or reduced expression, or elevated expression of proteins that are inhibitory at various steps in the pathway, may reduce or eliminate Fas-mediated apoptosis.

Thus, mutations in the death domain of Fas (Itoh and Nagata, 1993), expression of soluble Fas (sFas; Cheng et al, 1994), or reduced expression of the Fas antigen may result in resistance to Fas-dependent apoptosis, and reduced expression of Fas has been identified in certain colon carcinomas (Moller et al, 1994). Cells must also express sufficient levels of all components of the DISC to induce apoptosis. Inhibitory factors that may be expressed include FAP-1 (a Fas-associated phosphatase), which associates with the negative regulatory domain of the receptor to inhibit Fas signalling (Sato et al, 1995), and has been found to be expressed in colon carcinoma cell lines 
(Yanagisawa et al, 1997). In addition, high-level Bcl-2 expression has also prevented the function of the Fas pathway, and in this regard, decreased anti-Fas sensitivity has correlated with increased expression of $\mathrm{Bcl}-2$ in colorectal carcinomas (Meterissian and Kontogiannea, 1996), and colorectal carcinoma cell lines (Houghton et al, 1997a,b).

In the current study we have sequenced the death domain of Fas, which comprises a defined area encoding 65 amino acids responsible for promoting the death signal (Itoh and Nagata, 1993). In addition we have examined the expression of Fas, FADD/MORT1, FLICE, sFas, FAP-1 and $\mathrm{Bcl}-2$ in a series of 10 cultured colon carcinoma cell lines with defined and varied sensitivity to the cytolytic anti-Fas MoAb CH-11, and hence to Fas-mediated apoptosis. Data demonstrate no mutations in the death domain of Fas and while some variability exists in the expression of all genes examined, the greatest differential (>1000-fold) has occurred in the expression of the Fas antigen itself. Thus, cell lines with the greatest sensitivity to $\mathrm{CH}-11$, despite the presence of FAP-1, Bcl-2 and even sFas, also express the highest levels of Fas. In HT29 colon carcinoma cells with reduced Fas expression, levels of the receptor were elevated fourfold by treating cells with the cytokine interferon- $\gamma$, resulting in significantly enhanced sensitivity to Fas-mediated apoptosis. Results suggest that the most important determinant of Fas-dependent apoptosis in colon carcinoma cells may be the actual level of Fas expression.

\section{A: Growth inhibitiion}

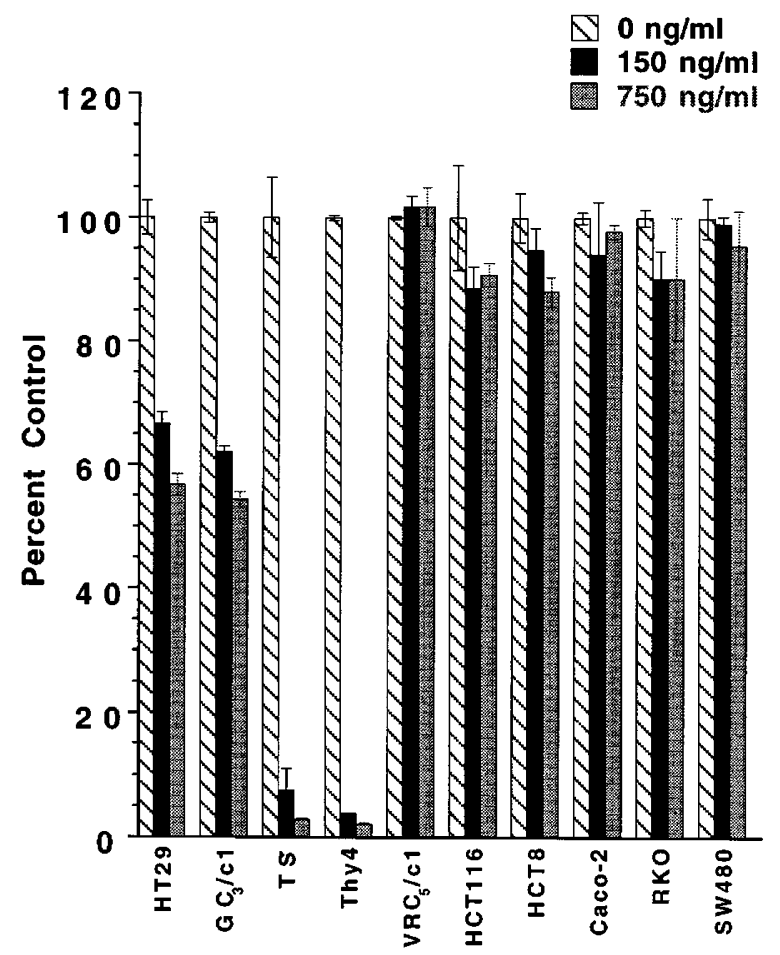

\section{Results}

\section{Fas-mediated apoptosis in colon carcinoma cell lines}

Previously we determined that Fas-mediated apoptosis could be induced in $\mathrm{GC}_{3} / \mathrm{c} 1$, TS ${ }^{-}$and Thy 4 cells by the cytolytic anti-Fas MoAb CH-11 (Houghton et al, 1997b). Subsequently we have compared the sensitivity of a series of 10 human colon carcinoma cell lines to $\mathrm{CH}-11$ at concentrations of $150 \mathrm{ng} / \mathrm{ml}$ and $750 \mathrm{ng} / \mathrm{ml}$ using both growth inhibition and clonogenic assays (Figure 1), and have found considerable variability in their responsiveness. $\mathrm{CH}-11$ inhibited the growth of $\mathrm{HT} 29$ and $\mathrm{GC}_{3} / \mathrm{c} 1$ cells to $<60 \%$ of control, and in $\mathrm{TS}^{-}$and Thy 4 to $<10 \%$ of control following a $72 \mathrm{~h}$ exposure (Figure 1A). Little influence of $\mathrm{CH}-11$ on the growth of the remaining six cell lines was detected. Subsequent evaluation of the cytotoxic response to $\mathrm{CH}-11$ following $72 \mathrm{~h}$ exposure by clonogenic assay indicated that the MoAb was growth inhibitory in HT29 cells, but was cytolytic in $\mathrm{GC}_{3} / \mathrm{c1}$, TS and Thy4 (Figure 1B). At $150 \mathrm{ng} / \mathrm{ml} \mathrm{CH}-11$, clonogenic survival was $21 \%$ in $\mathrm{GC}_{3} / \mathrm{c} 1$ and $<3 \%$ in $\mathrm{TS}^{-}$and Thy4, and at $750 \mathrm{ng} / \mathrm{ml}$, survival was $<1 \%$ in all three cell lines. No sensitivity to the IgG1 isotype-matched control MoAb was detected in any of the cell lines (data not shown).

Morphologic evidence of apoptosis was also obtained (Figure 2). Apoptosis induced in $\mathrm{TS}^{-}$, Thy4 and $\mathrm{GC}_{3} / \mathrm{c} 1$ cells treated with $\mathrm{CH}-11(15 \mathrm{ng} / \mathrm{ml})$ is shown at $11 \mathrm{~h}\left(\mathrm{TS}^{-}\right.$, Thy4) or $24 \mathrm{~h}\left(\mathrm{GC}_{3} / \mathrm{c} 1\right)$. Cells characteristically demonstrated chromatin condensation, nuclear fragmentation,

\section{B: Clonogenic Survival}

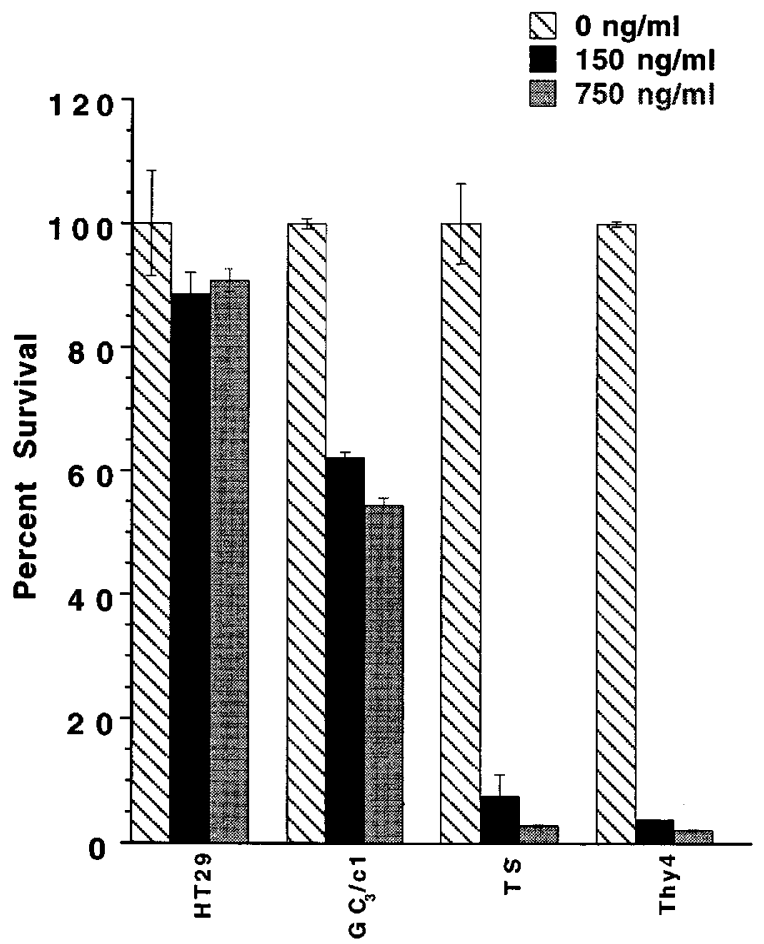

Figure 1 Growth inhibitory response (A) and clonogenic survival (B) of human colon carcinoma cell lines following $72 \mathrm{~h}$ exposure to $\mathrm{CH}-11$. Experimental conditions are as described in Materials and Methods. Results are the mean \pm S.D. of triplicate determinations for each condition 
cytoplasmic vacuoles and membrane blebbing. However, in HT29 cells which did not demonstrate a cytotoxic response to $\mathrm{CH}-11$, no morphologic evidence of apoptosis was obtained following treatment with $150 \mathrm{ng} / \mathrm{ml} \mathrm{CH}-11$. Morphologic evaluation of apoptosis correlated well with results obtained from clonogenic assays.

\section{Expression of Fas}

Fas expression was determined by RT-PCR (Figure 3) and further quantitated by ELISA (Table 1). Considerable variability in levels of receptor expression was demonstrated among the ten cell lines, where levels ranged from no expression in Caco-2 cells to $1262 \mathrm{pg} / 10^{6}$ cells in TS ${ }^{-}$. Levels of Fas were highest in the three cell lines where Fas-mediated apoptosis had been induced by $\mathrm{CH}-11\left(\mathrm{GC}_{3}\right)$ c1, $\mathrm{TS}^{-}$, Thy4), being highest in $\mathrm{TS}^{-}$cells and lowest in $\mathrm{GC}_{3} / \mathrm{c} 1$ (540 pg/10 $/ 10^{6}$ cells). In all other cell lines that were Fas-resistant, levels of Fas expressed were $<350 \mathrm{pg} / 10^{6}$ cells. To determine whether Fas expression or the ability

HT29

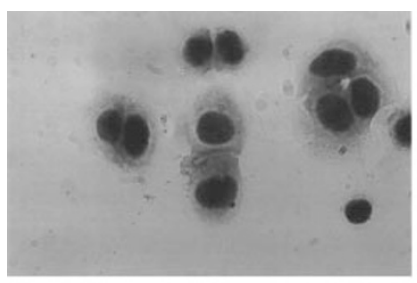

$\mathrm{TS}^{-}$

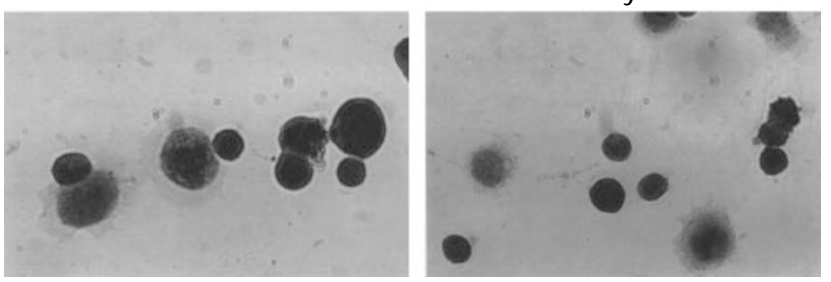

Figure 2 Morphologic evaluation of apoptosis in $\mathrm{HT}_{29}, \mathrm{GC}_{3} / \mathrm{c} 1, \mathrm{TS}^{-}$and Thy 4 cells. Experimental conditions are as described in Materials and Methods. No evidence of apoptosis was detected in HT29 cells, shown treated with $150 \mathrm{ng} / \mathrm{ml} \mathrm{CH}-11$ for $11 \mathrm{~h}$. However apoptotic cells were demonstrated in $\mathrm{GC}_{3} / \mathrm{c} 1$ following exposure to $\mathrm{CH}-11(15 \mathrm{ng} / \mathrm{ml})$ for $24 \mathrm{~h}$, and in $\mathrm{TS}^{-}$and Thy 4 cells following exposure to $\mathrm{CH}-11(15 \mathrm{ng} / \mathrm{ml})$ for $11 \mathrm{~h}$. Slides were examined by light microscopy using $\times 100$ magnification to induce Fas-dependent apoptosis may be due to modification or mutation in the death domain of the Fas antigen, the cDNA comprising the death domain was sequenced. In all cell lines except Caco-2 where no Fas expression was detected, wt sequence for Fas was demonstrated (Table 1).

\section{Expression of FADD/MORT1 and FLICE}

To determine whether other components of the DISC were present in Fas-resistant cell lines in comparison to Fassensitive cells, the expression of FADD/MORT1 and FLICE was examined by RT-PCR (Figure 4; Table 1). Levels of expression of both cell death regulatory factors varied by 8-9-fold (Table 1); both were lower in Fassensitive $\mathrm{GC}_{3} / \mathrm{c} 1$ cells than in e.g., RKO or SW480 cells where no Fas-mediated apoptosis was detectable. In Fasresistant Caco-2 cells, not only was the expression of Fas absent, but this cell line also demonstrated the lowest expression of FLICE. However, other than for FLICE in Caco-2 cells, there was no apparent relationship between the expression of the two cell death regulatory factors and cellular sensitivity to $\mathrm{CH}-11$ in the nine additional colon carcinoma cell lines.

\section{Expression of factors inhibitory to Fas signalling}

Expression of sFas, FAP-1 and Bcl-2 have, in several different systems, been found to be capable of inhibiting the ability of the Fas signalling pathway to mediate an apoptotic response.

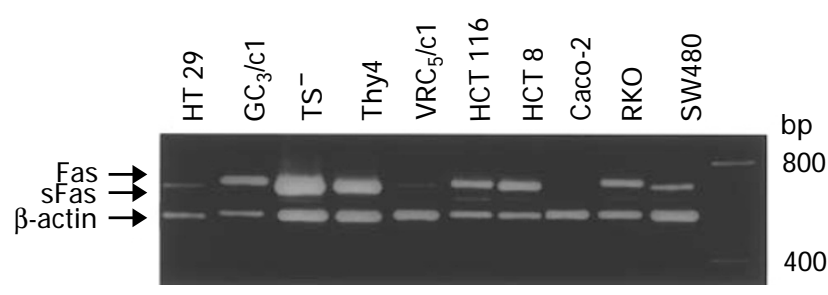

Figure 3 Expression of Fas determined by RT-PCR analysis. Cell extracts were prepared as described in Materials and Methods. PCR amplification was conducted following production of Fas CDNA to yield a $682 \mathrm{bp}$ product. sFas was also amplified to yield a $619 \mathrm{bp}$ product. $\beta$-actin control PCR (540 bp product) was simultaneously performed to monitor RT-PCR amplification efficiency

Table 1 Relative levels of expression of factors that influence Fas-mediated apoptosis in colon carcinoma cell lines

\begin{tabular}{|c|c|c|c|c|c|c|c|c|}
\hline \multicolumn{3}{|c|}{ Fas } & \multicolumn{5}{|c|}{ Relative O.D. } & \multirow{2}{*}{$\begin{array}{c}\mathrm{CH}-11 \\
\text { sensitivity }\end{array}$} \\
\hline Cell line & (pg/10 $10^{6}$ cells) & Fas seq & sFas & FAP-1 & FADD/MORT & FLICE & Bcl-2 & \\
\hline HT29 & 85 & wt & - & 3.1 & 5.1 & 4.9 & - & $+1-$ \\
\hline $\mathrm{GC}_{3} / \mathrm{c} 1$ & 540 & wt & 1.0 & 5.9 & 1.0 & 1.2 & 3.2 & + \\
\hline TS & 1262 & wt & 3.8 & 16.0 & 7.4 & 7.8 & 4.9 & ++ \\
\hline Thy4 & 743 & wt & 1.6 & 12.7 & 9.2 & 6.9 & 7.7 & +++ \\
\hline $\mathrm{VRC}_{5} / \mathrm{c} 1$ & 75 & wt & - & - & 5.5 & 2.2 & 2.1 & - \\
\hline HCT116 & 350 & wt & 8.8 & 1.8 & 3.5 & 5.8 & 1.0 & - \\
\hline HCT8 & 180 & wt & 2.9 & 8.9 & 5.4 & 8.4 & 3.4 & - \\
\hline Caco-2 & 0 & - & - & 3.0 & 3.4 & 1.0 & - & - \\
\hline RKO & 261 & wt & 3.3 & - & 4.9 & 6.8 & 2.5 & - \\
\hline SW480 & 175 & wt & 2.1 & 1.0 & 8.3 & 6.7 & 1.1 & - \\
\hline
\end{tabular}


Their relative levels of expression were therefore examined in this series of ten human colon carcinoma cell lines, and compared to the sensitivity of the lines to Fas-induced apoptosis.

There was a ninefold range in expression of sFas (Figure 3; Table 1), which was highest in Fas-resistant HCT116 cells and lowest in Fas-sensitive $\mathrm{GC}_{3} / \mathrm{c} 1$ and Thy4 cell lines. However, $\mathrm{TS}^{-}$cells expressed an intermediate level. SFas was not detected in $\mathrm{VRC}_{5} / \mathrm{c} 1$ or Caco- 2 cells, although these lines were Fas-insensitive.

Expression of FAP-1, which binds to the negative regulatory domain of Fas, varied by 16-fold among the ten cell lines, being highest however in the two lines most sensitive to Fas-mediated apoptosis ( $\mathrm{TS}^{-}$, Thy4) and very low or absent in Fas-resistant $\mathrm{VRC}_{5} / \mathrm{c} 1, \mathrm{RKO}$ and SW480 cell lines (Figure 5; Table 1). Of interest was that $\mathrm{TS}^{-}$and Thy4 also expressed the highest levels of the receptor in addition to the highest level of FAP-1.

Levels of Bcl-2 expression varied by eightfold (Figure 6; Table 1), and of interest Bcl-2 was highest in Thy4, the line most sensitive to Fas-induced apoptosis. Bcl-2 levels were lowest in Fas-resistant cells (HCT116, SW480), and data suggested no correlation between $\mathrm{Bcl}-2$ expression and Fas-induced apoptosis.

Taken together, data indicated that levels of expression of the negative regulators of Fas signalling examined including sFas, FAP-1 and Bcl-2, were not correlative with Fas-mediated apoptosis in colon carcinoma cell lines.

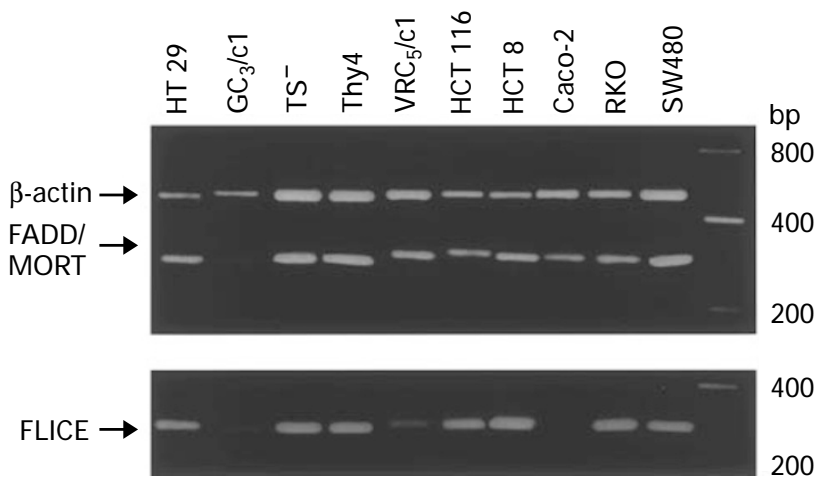

Figure 4 Expression of FADD/MORT1 and FLICE, components of the DISC and $\beta$-actin as internal control, in cell extracts. Conditions were as described in Materials and Methods

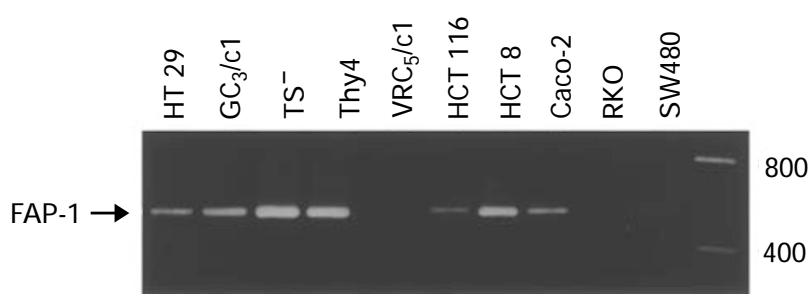

Figure 5 Levels of FAP-1 expressed in colon carcinoma cell lines following analysis by RT-PCR. $\beta$-actin expression is shown in Figure 2

\section{Upregulated expression of Fas by interferon- $\gamma$ increases sensitivity to Fas-mediated apoptosis}

From the data presented, it is evident that the strongest correlation between relative levels of expression of components of the Fas signalling pathway and Fasmediated apoptosis in colon carcinoma cell lines, comes from the levels of expression of the Fas antigen itself. Several reports have indicated that the expression of Fas may be modulated and upregulated either following transfection of human Fas antigen cDNA (Itoh et al, 1991) or following treatment of cells with certain cytokines including interferon- $\gamma$ or TNF- $\alpha$ (Leithauser et al, 1993; Moller et al, 1994; Ossina et al, 1997; Weller et al, 1994). To examine whether modulation of Fas expression could be achieved in colon carcinoma cells by cytokines, and if so, could enhance the sensitivity to Fas-dependent apoptosis, cells with relatively low (HT29) or intermediate (HCT8, HCT116) levels of expression of the receptor were initially treated with interferon- $\gamma(100 \mathrm{U} / \mathrm{ml})$ for a period of $48 \mathrm{~h}$, followed by examination of the level of elevation in Fas expression by ELISA assay (Table 1). Exposure to interferon- $\gamma$ for $48 \mathrm{~h}$ had been shown previously to maximally elevate Fas expression in HT29 cells (Moller et al, 1994). In each of the three cell lines, elevated Fas expression was obtained, where a modest 1.6-fold increase was found in HCT8 and HCT116 cells. However, the greatest elevation of 4.3-fold occurred in HT29, where Fas expression was increased to $417 \mathrm{pg} / 10^{6}$ cells.

To determine whether increased expression of Fas could increase cellular sensitivity to Fas-induced apoptosis, the influence of interferon- $\gamma(100 \mathrm{U} / \mathrm{ml})$ on the sensitivity of HT29 cells to $\mathrm{CH}-11 \quad(50-200 \mathrm{ng} / \mathrm{ml})$ was examined by both growth inhibition and clonogenic assays

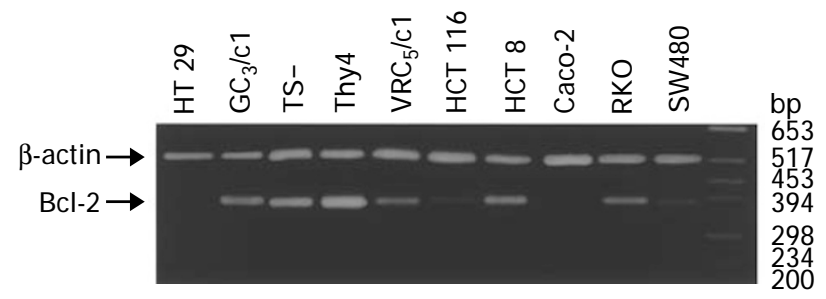

Figure $6 \mathrm{Bcl}-2$ expression in cultured colon carcinoma cells determined by $\mathrm{RT}-\mathrm{PCR}$ analysis and expression of $\beta$-actin

Table 2 Expression of Fas in colon carcinomaf cell lines after treatment with IFN- $\gamma$

\begin{tabular}{lrcc}
\hline Cell line & $\begin{array}{c}\text { IFN- } \gamma \\
(\mathbf{U} / \mathbf{m l})\end{array}$ & $\begin{array}{c}\text { Fas } \\
\left(\mathbf{p g} / 10^{6} \text { cells } \pm \text { S.D. }\right)\end{array}$ & $\%$ Control \\
\hline HT29 & 0 & $97.2 \pm 25.0$ & 100 \\
& 100 & $416.6 \pm 32.2$ & 429 \\
HCT8 & 0 & $200.0 \pm 25.0$ & 100 \\
& 100 & $325.0 \pm 25.0$ & 163 \\
HCT116 & 0 & $358.4 \pm 29.2$ & 100 \\
& 100 & $569.4 \pm 28.8$ & 159 \\
\hline
\end{tabular}


following exposure to the cytokine prior to (24 h) and during (72 h) $\mathrm{CH}-11$ exposure (Figure 7). Interferon- $\gamma$ and $\mathrm{CH}-11$ each induced a $15-40 \%$ inhibition of growth when administered alone. However, in combination, the growth inhibitory response was $>95 \%$, indicating a greater than additive effect for the cytokine and cytolytic $\mathrm{Ab}$ administered in combination. When examined by clonogenic assay, the growth inhibitory response of HT29 cells was found to be due to the induction of a cytotoxic response. Interferon- $\gamma$ and $\mathrm{CH}-11$ each administered alone exerted no effect on the clonogenic survival of HT29 cells. However, in combination, they induced $90 \%$ reduction in cellular survival at $50 \mathrm{ng} / \mathrm{ml} \mathrm{CH}-11$, and $>95 \%$ at a $\mathrm{CH}-11$ concentration of $200 \mathrm{ng} / \mathrm{ml}$, clearly demonstrating greater than additive effects. Therefore, the initial growth inhibitory response to $\mathrm{CH}-11$ observed in HT29 cells was enhanced and converted to an apoptotic response when upregulated expression of Fas was induced by treatment with interferon- $\gamma$, thereby sensitizing cells to Fas-mediated apoptosis.

\section{Discussion}

It is well established that Fas is expressed and has a functional role in the induction of apoptosis and maintenance of cellular homeostasis in cells of the immune system. Specifically, Fas has been implicated in the peripheral deletion of autoimmune cells, activation-induced $\mathrm{T}$ cell death, and is one of the major pathways of $\mathrm{CD}^{+}$cytolytic $\mathrm{T}$ cells (French et al, 1996). However, Fas is constitutively expressed in a variety of epithelial cell types including all cells of the colon, although whether Fas exerts a similar functional role in the maintenance of normal cell turnover and homeostasis in epithelial tissues still remains to be explored. We have shown previously that Fas-dependent apoptosis can occur in malignant cells of the colon (Houghton et al, 1997a,b). However, malignant colonic epithelial cells frequently demonstrate reduced capabilities of responding to apoptotic stimuli either by mutation of genes involved in promoting responses downstream of DNA damage including the p53 tumor suppressor gene (Fearon and Vogelstein,

\section{A: Growth inhibitiion}

\section{B: Clonogenic Survival}
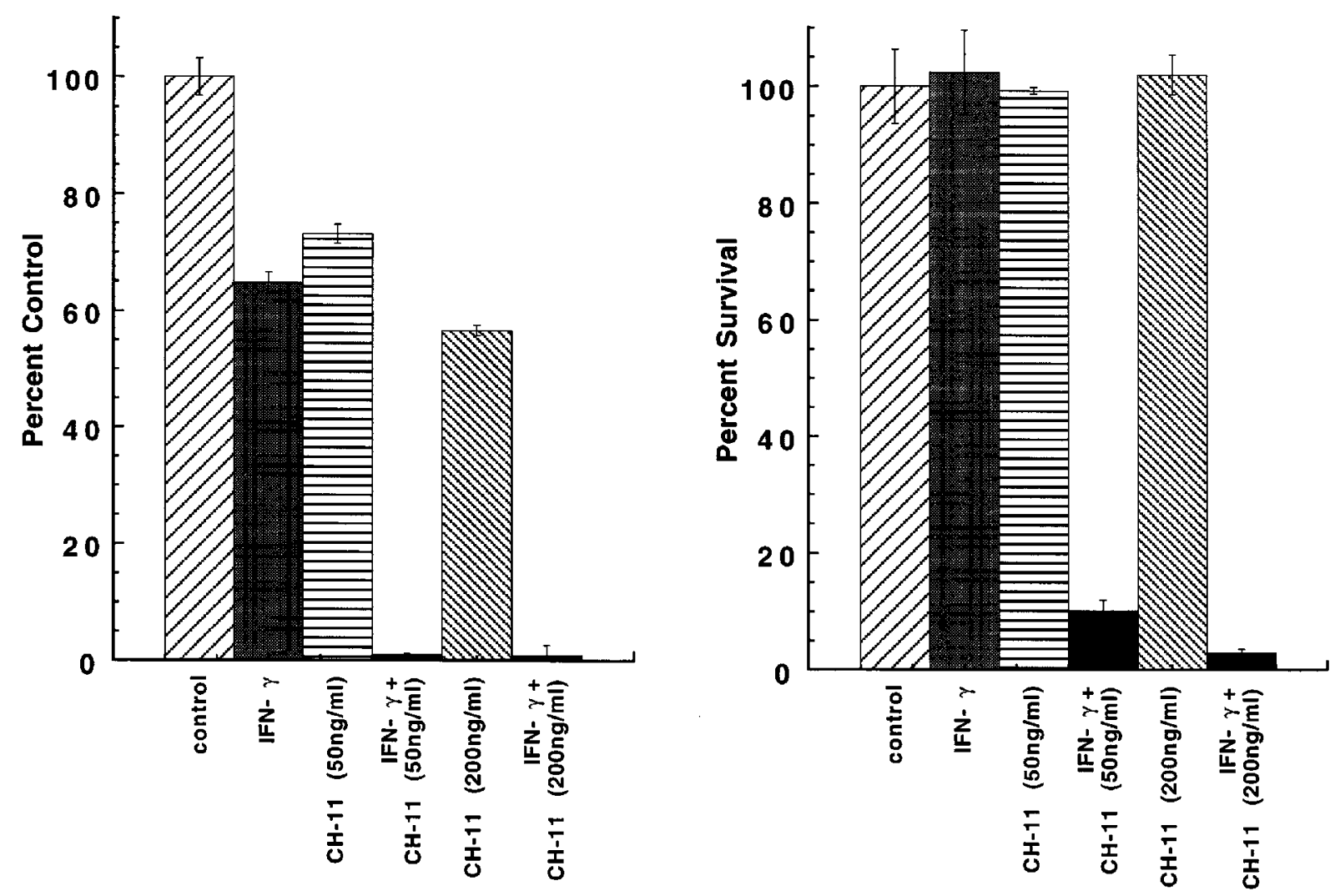

Figure 7 Sensitivity of $\mathrm{HT} 29$ cells to $\mathrm{CH}-11$ and interferon- $\gamma$ administered singly or in combination. (A) Growth inhibition induced by interferon- $\gamma$ (100 U/ml) administered for $96 \mathrm{~h}$ or $\mathrm{CH}-11(50 \mathrm{ng} / \mathrm{ml}, 200 \mathrm{ng} / \mathrm{ml})$ administered for $72 \mathrm{~h}$. Alternatively, $\mathrm{HT} 29$ cells were treated with interferon- $\gamma 24 \mathrm{~h}$ prior to a $72 \mathrm{~h}$ exposure to $\mathrm{CH}-11$ simultaneously with interferon- $\gamma$ for a further $72 \mathrm{~h}$. Cells were enumerated at the end of the treatment period. (B) Clonogenic survival of HT29 cells following administration of interferon- $\gamma$ and $\mathrm{CH}-11$ either alone or in combination. Plating conditions were as described in Materials and Methods, and treatment conditions were as described in $\mathbf{A}$. Colonies were enumerated 6 days following the removal of $\mathrm{CH}-11$ 
1990), reduced expression of genes required to promote a cell death signal (e.g. reduced expression of the Fas antigen; Moller et al, 1994), or elevated expression of genes that promote cellular survival (Bcl-2; Bedi et al, 1995) or inhibit essential signalling pathways (e.g. FAP-1; Yanagisawa et al, 1997). We have therefore defined the cellular sensitivity to Fas-mediated apoptosis in 10 human colon carcinoma cell lines and have determined the expression of genes known to regulate the function of the Fas signalling pathway in the induction of Fas-dependent apoptosis.

Four of the ten cell lines demonstrated some sensitivity to the cytolytic $\mathrm{CH}-11 \mathrm{MoAb}$ and of these, cell death was induced in three of the four, as determined by reduced clonogenic survival and morphologic evaluation of the presence of apoptotic cells. However, six lines were resistant to the induction of Fas-dependent apoptosis, suggesting that the ability to tightly regulate this apoptotic pathway had been reduced or eliminated. The importance of the death domain for Fas signalling has been well established (Itoh and Nagata, 1993). Lpr ${ }^{\text {cg }}$ mice carry a point mutation located within the Fas death domain resulting in signalling deficiency (Watanabe-Fukunaga et al, 1992), and mutations in Fas are associated with human lymphoproliferative disorders and autoimmune disease (Rieux-Laucat et al, 1995). However, in the panel of colon carcinoma cell lines investigated, sequencing analyses indicated that the Fas death domain in nine of the lines was of wt sequence, indicative of the ability to maintain promotion of an apoptotic stimulus. Fas expression was undetectable in Caco-2 cells, although the reason for this loss of expression is at present unknown.

Downstream of Fas, the $28 \mathrm{kd}$ cytosolic protein FADD/ MORT1, an essential component of the DISC, also contains a death domain and induces apoptosis when overexpressed in different cell types (Boldin et al, 1995; Chinnaiyan et al, 1995). Its importance to Fas signalling was established when transfection of a dominant negative FADD/MORT1 (FADD-DN) prevented recruitment of the other CAP proteins to the DISC, thereby preventing the induction of apoptosis (Chinnaiyan et al, 1996). In the current study, all ten colon carcinoma cell lines appeared to demonstrate adequate FADD/MORT1 expression, since the cell line with the lowest level of expression $\left(\mathrm{GC}_{3} / \mathrm{c} 1\right)$ was one of the lines most sensitive to Fas-mediated apoptosis. Similarly FLICE, another key component of the DISC, has been identified as an important regulator of the induction of apoptosis downstream of Fas (Boldin et al, 1996; Muzio et al, 1996). The recent cloning of a naturally occurring structural homolog of FLICE (I-FLICE) which exerts dominant negative function, was found to inhibit Fasdependent apoptosis ( $\mathrm{Hu}$ et al, 1997). Although the lowest level of FLICE expression was found in Caco-2 cells, which also demonstrated no Fas expression, levels of FLICE appeared adequate in all of the other cell lines, being low in $\mathrm{GC}_{3} / \mathrm{c} 1$ which was Fas-sensitive.

Protection from Fas-mediated apoptosis by a soluble form of the Fas molecule has been identified (Cheng et al, 1994). SFas lacks the transmembrane domain due to the deletion of an exon encoding the region, and has been identified in patients with systemic lupus erythematosus
(Cheng et al, 1994) and in the serum and tumors of patients presenting with solid malignancies (Midis et al, 1996). The expression of sFas was detected in Fasresistant HCT116 colon carcinoma cells, but was also present in $\mathrm{TS}^{-}$cells, which were sensitive to Fas-mediated apoptosis. Levels of sFas appeared insignificant in comparison to the higher levels of Fas expressed in the same cell lines, suggesting that the presence of sFas did not confer Fas resistance. The expression of other proteins that interfere with Fas signalling include FAP-1, which is an inhibitory Fas-binding protein that interacts with the Cterminal 15 amino acids of the regulatory domain of the Fas receptor (Sato et al, 1995). FAP-1 has been identified in cultured colon carcinoma cells (Yanagisawa et al, 1997), and its expression was reported to be highest in cell lines and tissues that are relatively resistant to Fas-mediated cytotoxicity (Sato et al, 1995). However, others have shown that cell lines extremely sensitive to Fas-induced apoptosis (HUT78, SKW6.4) expressed high levels of FAP-1, whereas a Fas-resistant line was completely negative for FAP-1 mRNA (Boe ${ }^{\text {; }}$ Peter et al, 1996). In agreement with the latter report, colon carcinoma cell lines in the current study that were highly sensitive to the induction of apoptosis via Fas also expressed the highest levels of FAP-1. Expression of Bcl-2, which has been reported to negatively correlate with anti-Fas sensitivity in colorectal carcinomas (Meterissian and Kontagiannea, 1996) and cell lines (Houghton et al, 1997a,b), was also examined. However, cell lines that were the most sensitive to $\mathrm{CH}-11$ (TS ${ }^{-}$, Thy4) also expressed the highest levels of $\mathrm{Bcl}-2$, indicating no direct correlation between high $\mathrm{Bcl}-2$ expression and low anti-Fas sensitivity.

It should be emphasized however, that while no relationship has been found between relative expression of certain key regulatory factors as determined by RTPCR, and Fas response, relative levels of expression of the respective proteins have yet to be determined. The activities of these proteins may also be influenced by their intracellular location, phosphorylation state and/or other posttranslational modifications, and hence may also influence Fas signalling processes beyond the level of RNA expression.

Of particular interest in the current study was the large diversity in levels of expression of the Fas antigen itself in the ten human colorectal carcinoma cell lines, where levels of the receptor varied by $>1000$-fold. $\mathrm{TS}^{-}$, Thy 4 and $\mathrm{GC}_{3} /$ c1 cell lines with the highest sensitivity to Fas-induced apoptosis also demonstrated the highest levels of Fas expression ( $>540 \mathrm{pg} / 10^{6}$ cells); cell lines with Fas levels of $<350 \mathrm{pg} / 10^{6}$ cells were all Fas-resistant. In $\mathrm{TS}^{-}$and Thy4, high-level Fas expression may be responsible for negating the inhibitory effects of high levels of expression of FAP-1 or $\mathrm{Bcl}-2$ in these cell lines. Variability in levels of Fas expression did not appear to be due to mutation in the death domain of Fas. Previous reports indicated that cytokines including interferon- $\gamma$ can elevate the expression of Fas in epithelial cell lines (Leithauser et al, 1993; Moller et al, 1994; Ossina et al, 1997). Our studies demonstrated that modest elevation in Fas expression was achieved in HCT8 and HCT116 cells following treatment of cells with 
interferon- $\gamma$, but a significant elevation (4.3-fold) was achieved in HT29. These data are consistent with a previous report indicating varied inducibility of Fas expression in colon carcinoma cell lines (Moller et al, 1994). However, of particular interest, was that pretreatment of HT29 cells with interferon- $\gamma$ prior to $\mathrm{CH}-11$ was synergistic in the induction of Fas-dependent cytotoxicity. In this cell line, a growth inhibitory response was converted to a cytotoxic response, simultaneous with upregulated expression of Fas. Other cytokines including TNF- $\alpha$ have also been found to be capable of inducing Fas expression (Leithauser et al, 1993; Moller et al, 1994; Weller et al, 1994), and a combination of cytokines has been shown to exert greater effects than single agents in this regard (Moller et al, 1994). Our study has demonstrated that the level of Fas expression may be a major determinant of Fasdependent apoptosis in colon carcinoma cells, and that modulation of receptor expression can significantly influence the ability of these cells to respond to Fas signalling, and to the induction of apoptosis via Fas.

Previously we have shown that autocrine signalling via Fas/FasL interactions promotes thymineless death following the induction of DNA damage by dThd withdrawal in $\mathrm{TS}^{-}$ cells, thereby linking DNA damage to the apoptotic machinery of colon carcinoma cells (Houghton et al, 1997a). Hence the Fas signalling pathway may be an essential functional pathway for the induction of apoptotic responses in colon carcinoma cells, and may be important in the regulation of apoptosis in malignant epithelial cells treated with agents that target thymidylate synthase. As a mediator of apoptosis in response to treatment with chemotherapeutic agents the role of Fas is worthy of further exploration. The significance of the level of Fas in colon carcinoma cells and the ability to upregulate Fas expression using cytokines to promote apoptosis indicate that Fas may be an important target to explore further in the modulation of apoptotic responses in colon carcinomas.

\section{Materials and Methods}

\section{Cell lines}

The cloned human colon adenocarcinoma cell lines $\mathrm{GC}_{3} / \mathrm{c} 1$ (Houghton et al, 1995) and $\mathrm{VRC}_{5} / \mathrm{c} 1$ (Houghton et al, 1991) have been described previously. A thymidylate synthase-deficient mutant clone selected from $\mathrm{GC}_{3} / \mathrm{c} 1, \mathrm{TS}^{-}$, deficient in TSmRNA and protein and auxotrophic for dThd, has been well characterized (Harwood et al, 1996). A clone of $\mathrm{TS}^{-}$, Thy4, was selected for its ability to withstand prolonged periods of dThd deprivation (Harwood et al, 1996). RKO cells were a gift from Dr Michael Kastan, Johns Hopkins Medical Center. All additional colon carcinoma cell lines used for these studies were obtained from ATCC. Cells were maintained as previously described (Harwood et al, 1996), in the presence of $20 \mu \mathrm{M}$ dThd.

\section{Growth and clonogenic assays}

For growth inhibition assays, cells were plated in 6-well plates (Falcon) at a density of 100000-200000 cells/well. Following overnight attachment, cells were treated with the anti-Fas cytolytic $\mathrm{MoAb} \mathrm{CH}$ 11 (MBL International Corp.), or an IgG1 isotype-matched control
(Pharmingen) at concentrations from $150-750 \mathrm{ng} / \mathrm{ml}$ for $72 \mathrm{~h}$. Alternatively, cells were treated with interferon- $\gamma(100 \mathrm{U} / \mathrm{ml}$; Genentech Inc.) for $24 \mathrm{~h}$ prior to exposure to $\mathrm{CH}-11(50-200 \mathrm{ng} / \mathrm{ml})$ for a further $72 \mathrm{~h}$. Cells were subsequently enumerated using a Coulter particle counter.

For clonogenic assays, $\mathrm{GC}_{3} / \mathrm{c} 1, \mathrm{TS}^{-}$and Thy 4 cells were plated at a density of 3000 cells/well, and HT29 at 1000 cells/well. Following overnight attachment, media was aspirated and cells were treated with $\mathrm{CH}-11(150-750 \mathrm{ng} / \mathrm{ml})$ for $72 \mathrm{~h}$. Clonogenic survival was evaluated 6 days (HT29), 7 days $\left(\mathrm{GC}_{3} / \mathrm{C} 1\right)$ or 11 days (TS ${ }^{-}$, Thy 4$)$ after removal of $\mathrm{CH}-11$ (Harwood et al, 1996).

\section{Morphologic identification of apoptosis}

$\mathrm{HT29}, \mathrm{GC}_{3} / \mathrm{c} 1, \mathrm{TS}^{-}$and Thy4 cells which demonstrated varied sensitivity to Fas-mediated apoptosis induced by $\mathrm{CH}-11$, were examined for morphologic evidence of apoptosis. Cells were plated in glass chamber slides each containing two chambers (Nunc LabTek\#154461) under standard conditions at plating densities of 100000 or 400000 cells/well in a volume of $2 \mathrm{ml}$. Following overnight attachment, cells were treated with $\mathrm{CH}-11(15-150 \mathrm{ng} / \mathrm{ml})$ diluted in sterile PBS or PBS alone $(20 \mu \mathrm{l})$ for $11 \mathrm{~h}$ or $24 \mathrm{~h}$. Cells were subsequently fixed in paraformaldehyde and stained with hematoxylin and eosin using standard procedures.

\section{Expression of Fas, FADD/MORT1, FLICE, sFas, FAP-1 and Bcl-2}

The expression of components of the Fas signalling pathway (Fas, FADD/MORT1, FLICE) and factors inhibitory to Fas-mediated apoptosis (sFas, FAP-1, Bcl-2), were examined in ten human colon carcinoma cell lines.

Fas expression was determined in cell extracts either by RT - PCR to yield a 682 bp product (O'Connell et al, 1996), or by a standard ELISA assay (Houghton et al, 1997a). The capture Ab used was a purified antihuman Fas MoAb (Pharmingen; cat.\#65311A), whereas the Ab used for detection was a biotin anti-human Fas MoAb DX2 (Pharmingen). Quantitation was by optical densitometry using recombinant soluble human Fas (Pharmingen) as the standard, and normalized for cell number as previously described (Houghton et al, 1997a).

FADD/MORT1, FLICE, FAP-1 and Bcl-2 were also determined by RT-PCR. Total RNA was extracted from cells in RNAzol B; CDNA was synthesized in a volume of $20 \mu \mathrm{l}$ from $2 \mu \mathrm{g}$ total RNA using an oligo dT primer and a cDNA cycle kit (InVitrogen). B-actin control PCR (540 bp product) was performed to monitor RT-PCR amplification efficiency (O'Connell et al, 1996). PCR amplification of FAP-1 (Sato et al, 1995) and Bcl-2 (Mori et al, 1996) cDNAs was performed as described to yield $607 \mathrm{bp}$ and $389 \mathrm{bp}$ products, respectively. Forward and reverse primers used to amplify FADD/MORT1 and FLICE to produce $291 \mathrm{bp}$ and 273 bp products, respectively, were: FADDF, 5'-GAAGAAGACCTGTGTGCAGC-3'; FADDR, 5'-ACTCCTGTTCTGGAGGTCAC3'; FLICEF, 5'-GAGGAGTTGTGTGGGGTAATGA-3'; FLICER, 5'CTCTACTGTGCAGTCATCGTG-3'. In addition, the death domain of Fas was sequenced by dideoxynucleotide sequencing of a Fas F3-R3 $\mathrm{PCR}$ product synthesized from cDNA prepared from each cell line (Sato et al, 1995).

\section{Acknowledgements}

This research was supported by NIH Awards R37 CA 32613, the Cancer Center Support (CORE) Grant CA 21765 and by the American Lebanese Syrian Associated Charities (ALSAC). 


\section{References}

Bedi A, Pasricha PJ, Akhtar AJ, Barber JP, Bedi GC, Giardiello FM, Zehnbauer BA Hamilton SR and Jones RJ (1995) Inhibition of apoptosis during development of colorectal cancer. Cancer Res. 55: 1811-1816

Boldin MP, Varfolomeev EE, Pancer Z, Mett IL, Camonis JH and Wallach D (1995) A novel protein that interacts with the death domain of Fas/APO1 contains a sequence motif related to the death domain. J. Biol. Chem. 270: 7795-7798

Boldin MP, Goncharov TM, Goltsev YV and Wallach D (1996) Involvement of MACH, a novel MORT1/FADD-interacting protease, in Fas/APO-1-and TNF receptorinduced cell death. Cell 85: 803-815

Cheng J, Zhou T, Liu C, Shapiro JP, Brauer MJ, Kiefer MC, Barr PJ and Mountz JD (1994) Protection from Fas-mediated apoptosis by a soluble form of the Fas molecule. Science 263: 1759-1762

Chinnaiyan AM, O'Rourke K, Tewari M and Dixit VM (1995) FADD, a novel death domain-containing protein, interacts with the death domain of Fas and initiates apoptosis. Cell 81: 505-512

Chinnaiyan AM, Tepper CG, Seldin MF, O'Rourke K, Lou L, Kischkel FC, Hellbardt S, Krammer PH, Peter ME and Dixit VM (1996) FADD/MORT1 ia a common mediator of Fas/APO-1- and tumor necrosis factor-induced apoptosis. J. Biol. Chem. 271: $4961-4965$

Fearon ER and Vogelstein BA (1990) A genetic model for colorectal tumorigenesis. Cell 61: $759-767$

French LE, Hahne M, Viard I, Radlgruber G, Zanone R, Becker, K., Muller C and Tschopp J (1996) Fas and Fas ligand in embryos and adult mice: ligand expression in several immune-privileged tissues and coexpression in adult tissues characterized by apoptotic cell turnover. J. Cell Biol. 133: 335-343

Harwood FG, Frazier MW, Krajewski S, Reed JC, Houghton JA. (1996) Acute and delayed apoptosis induced by thymidine deprivation correlates with expression of p53 and p53-regulated genes in colon carcinoma cells. Oncogene 12: 2057 2067

Houghton JA, Adkins DA, Rahman A and Houghton PJ (1991) Interaction between 5fluorouracil, [6RS]leucovorin, and recombinant human interferon- $\alpha 2 a$ in cultured colon adenocarcinoma cells. Cancer Commun. 3: 225-231

Houghton JA, Harwood FG and Tillman DM (1997a) Thymineless death in colon carcinoma cells is mediated via Fas signalling. Proc. Natl. Acad. Sci. USA 94: 8144-8149

Houghton JA, Harwood FG, Gibson AA and Tillman DM (1997b) The Fas signalling pathway is functional in colon carcinoma cells and induces apoptosis. Clin. Cancer Res., in press

Houghton JA, Tillman DM and Harwood FG. (1995) Ratio of 2'-deoxyadenosine-5'triphosphate/thymidine-5'-triphosphate influences the commitment of human colon carcinoma cells to thymineless death. Clin. Cancer Res. 1: 723-730

Hu S, Vincenz C, Ni J, Gentz R and Dixit VM (1997) I-FLICE, a novel inhibitor of tumor necrosis factor receptor-1 and CD-95-induced apoptosis. J. Biol. Chem. 272: $17255-17257$

Itoh $\mathrm{N}$ and Nagata S (1993) A novel protein domain required for apoptosis. J. Biol. Chem. 268: $10932-10937$

Itoh N, Yonehara S, Ishii A, Yonehara M, Mizushima S-I, Sameshima M, Hase A, Seto $Y$ and Nagata S (1991) The polypeptide encoded by the cDNA for human cell surface antigen Fas can mediate apoptosis. Cell 66: 233-243

Leithauser F, Dhein J, Mechtersheimer G, Koretz K, Bruderlein S, Henne C, Schmidt A, Debatin K-M, Krammer PH and Moller P (1993) Constitutive and induced expression of APO-1. a new member of the nerve growth factor/tumor necrosis factor receptor superfamily, in normal and neoplastic cells. Lab. Invest. 69:415429
Medema JP, Scaffidi C, Kischkel FC, Shevchenko A, Mann M, Krammer P and Peter M (1997) FLICE is activated by associatioin with the CD95 death-inducing signaling complex (DISC). EMBO J. 16: 2794-2804

Meterissian S and Kontogiannea M. (1996) Fas antigen expression and function in human colorectal carcinoma. Correlation with Bcl-2 expression. Proc. Am. Assoc. Cancer Res. 37: 15

Midis GP, Shen Y and Owen-Schaub LB (1996) Elevated soluble Fas (sFas) levels in nonhematopoietic human malignany. Cancer Res. 56: 3870-3874

Moller P, Koretz K, Leithauser F, Bruderlein S, Henne C, Quentmeier A and Krammer $P$ (1994) Expression of Apo-1 (CD95), a member of the NGF/TNF receptor superfamily, in normal and neoplastic colon epithelium. Int. J. Cancer 57: 371 377

Mori S, Murakami-Mori K, Jenett A, Nakamura S and Bonavida B (1996) Resistance of AIDS-associated Kaposi's sarcoma cells to Fas-mediated apoptosis. Cancer Res. 56: 1874-1879

Muzio M, Chinnaiyan AM, Kischkel FC, O'Rourke K, Shevchenko A, Ni J, Scaffidi C, Bretz JD, Zhang M, Gentz R, Mann M, Krammer PH, Peter ME and Dixit VM (1996) FLICE, a novel FADD-homologous ICE/CED-3-like protease, is recruited to the CD95 (Fas/APO-1) death-inducing signaling complex. Cell 85: 817-827

O'Connell J, O'Sullivan GC, Collins JK and Shanahan F (1996) The Fas counterattack: Fas-mediated T cell killing by colon cancer cells expressing Fas ligand. J. Exp. Med. 184: 1075-1082

Ossina NK, Cannas A, Powers VC, Fitzpatrick PA, Knight JD, Gilbert JR, Shekhtman EM, Tomei D, Umansky SR and Kiefer MC (1997) Interferon- $\gamma$ modulates a p53independent apoptotic pathway and apoptosis-related gene expression. J. Biol. Chem. 272: $16351-16357$

Peter ME, Kischkel FC, Hellbardt S, Chinnaiyan AM, Krammer PH and Dixit VM (1996) CD95 )APO-1/Fas)- associating signalling proteins. Cell Death Differ. 3: $161-170$

Rieux-Laucat F, Le Deist F, Hivroz C, Roberts IAG, Debatin KM, Fischer A and de Villartay JP (1995) Mutations in Fas associated with human lymphoproliferative syndrome and autoimmunity. Science 268: 1347-1349

Rokhlin OW, Bishop GA, Hostager BS, Waldschmidt TJ, Sidorenko SP, Pavloff N, Kiefer MC, Umansky SR, Glover RA and Cohen MB (1997) Fas-mediated apoptosis in prostatic carcinoma cell lines. Cancer Res. 57: 1758-1768

Sato T, Irie S, Kitada S and Reed JC (1995) FAP-1: A protein tyrosine phosphatase that associates with Fas. Science 268: $411-415$

Suda T, Takahashi T, Golstein P and Nagata S (1993) Molecular cloning and expression of the Fas ligand, a novel member of the TNF family. Cell 75: 1169 1178

Trauth BC, Klas C, Peters AMJ, Matzku S, Moller P, Falk W, Debatin K-M and Krammer PH (1989) Monoclonal antibody-mediated tumor regression by induction of apoptosis. Science 245: 301-305

Watanabe-Fukunaga R, Brannan Cl, Copeland NG, Jenkins NA and Nagata S (1992) Lymphoproliferation disorder in mice explained by defects in Fas antigen that mediates apoptosis. Nature 356: 314-317

Weller M, Frei K, Groscurth P, Krammer PH, Yonekawa Y and Fontana A (1994) AntiFas/APO-1 antibody-mediated apoptosis of cultured human glioma cells. J. Clin. Invest. 94: 954-964

Yanagisawa J, Takahashi M, Kanki H, Yanagisawa HY, Tazunoki T, Sawa E, Nishitoba T, Kamishohara M, Kobayashi S and Sato T (1997) The molecular interaction of Fas and FAP-1. J. Biol. Chem. 272: 8539-8545 